\title{
Bacteria as agents of biocontrol of phytopathogens after laser stimulation and of their metabolites' impact on plants
}

\author{
Marina $V$. Maslova ${ }^{1, *}$, Ekaterina $V$. Grosheva ${ }^{1}$, Andrey $V$. Budagovsky ${ }^{1}$, and Olga. $N$. \\ Budagovskaya $^{1}$ \\ ${ }^{1}$ Michurinsk State Agrarian University, Research Problem Laboratory "Biophotonics", 393760 \\ Michurinsk, Tambov region, Russia
}

\begin{abstract}
The problem of increasing activity of phytopathogen antagonist bacteria under the influence of laser irradiation is considered in this paper. Studies on Bacillus subtilis and Pseudomonas fluorescens from various plant protection products have shown that use of laser irradiation leads to an increase in the number of cells in bacterial suspensions. This indicator increased to a maximum of two times at effective exposures in comparison with the non-irradiated variants. That was justification for the need to study the nature of the impact of excessive content of metabolites in the substrate synthesized by such a quantity of bacteria from biological products, which is 2 or more times higher than the number of cells in the standard solutions. With a twofold and fourfold increase in the concentration of metabolites of the studied bacteria compared to their standard content in the medium, the photosynthetic activity of cucumber microplants increased by more than $32 \%$. This suggests that laser stimulation of bacteria - agents of biocontrol of diseases does not adversely affect the functional state of plants.
\end{abstract}

\section{Introduction}

In connection with development and implementation of the organic farming concept, the introduction of biological control of phytopathogens in agricultural practice is an urgent and promising scientific direction against plant diseases. Application of biological agents is an environmentally friendly method of plant protection [1].

The ability of bacteria to synthesize biologically active substances is one of the most important factors determining interaction between bacteria and plants. Currently, biological products based on bacteria of the genera Pseudomonas and Bacillus have been developed, which are balanced in a complex of biologically active compounds (vitamins, phytohormones, enzymes, amino acids, polysaccharides, antibiotic substances that act against phytopathogenic bacteria and fungi) [2-7].

Treatment of plants with bacterial suspensions and metabolites has a stimulating effect on their growth, it changes the microbial cenosis by displacement of phytopathogenic microorganisms. One of the factors that can affect the causative agents of diseases that

\footnotetext{
* Corresponding author: marinamaslova2009@mail.ru
} 
interact with the plant is the ability of bacteria of protective biological products to form various low molecular weight substances, such as antibiotics.

Lately, the issue of increasing activity of phytopathogens' bacteria-antagonists has been relevant. Previously, the stimulating effect of laser irradiation on bacteria was found. The experiments showed that a short-term coherent light treatment of Pseudomonas fluorescens and Bacillus subtilis can increase their activity. The stimulating effect is based on the photoregulatory effect of red quasi-monochromatic radiation. Under its influence, the microbial cells begin to multiply faster, which leads to an increase in their fungicidal properties [8]. Changes in the functional activity and number of bacteria as a result of laser irradiation can lead to excessive accumulation of bacterial metabolites in the soil, including auxin-like substances, which in turn affect the physiological processes of plants. The action of exogenous auxins is similar to the action of phytohormones [9].

However, unlike the abovementioned substances, the plant is not able to control the duration of this action. Excess auxins may interfere with the normal functioning of the plant organism as a whole and cause an herbicidal effect. A number of auxin-like herbicides are known: phenoxyacetic acids, benzoic acids, quinoline carboxylic acids, pyridine carboxylic acids. In case of excessive accumulation of these substances in the plant, a number of processes are initiated that inhibit the growth of shoots and roots in length and oxidation. When exposed to hormone-like plant herbicides, the cell size increases and does not have time to stock up nutrients, which leads to their depletion and death. Due to the fact that further auxin-like substances affect various metabolic processes, the normal functioning of the plant as a whole is subsequently disturbed $[10,11,12]$.

When developing methods for laser stimulation of phytopathogen antagonists, it is necessary to take into account the possibility of excessive synthesis of microbial metabolites. In this regard, the aim of the work was to assess the nature of the effect on plants of high concentrations of bacterial metabolites - agents for the biocontrol of diseases after laser stimulation.

\section{Materials and methods}

The studies were conducted on the basis of the research laboratory "Biophotonics" at Michurinsk State Agrarian University in 2014-2019. We used bacteria from biological products of plant protection of Russian manufacturers:

- Bacillus subtilis VIZR - 10 (BsA) from "Alirin-B” (“Agrobiotechnology");

- Bacillus subtilis M - 22 VIZR (BsG) from “Gamair” (“Agrobiotechnology”);

- Bacillus subtilis (BsP) from "Pralin-Extra" ("BIOM-TORG”);

- Pseudomonas fluorescens (PfV) from "Vitaplan - Extra" ("BIOM-TORG”);

- Pseudomonas fluorescens AP-33 (PfR) from "Risoplan" ("Biopesticides").

During the experiments we used following growth media for the cultivation of microorganisms: Czapek medium and Sabouraud agar [13]; for plants - Murashige and Skoog medium [14].

\subsection{Determination of the number of colony-forming units (CFU) in a bacterial suspension}

A suspension of microorganisms from each variant was taken with a sterile pipette of $100 \mu \mathrm{l}$ and plated on a solid Sabouraud agar in Petri dishes. The cultures were incubated for one day at a temperature of $37^{\circ} \mathrm{C}$. Then, the grown colonies were counted in a Petri dish, followed by recounting per $1 \mathrm{ml}$ of suspension. 


\subsection{Laser irradiation of bacteria}

Bacterial suspensions were treated with coherent light using helium-neon and semiconductor lasers with a power density of $2.0-2.5 \mathrm{~W} / \mathrm{m}^{2}$ and exposure durations of $15,30,60,120,240$, 480, and 960 seconds.

\subsection{Impact of bacterial metabolites - agents of biocontrol of phytopathogens on plants in vitro}

A solution of metabolites was obtained by culturing bacteria in a liquid Czapek medium for a month at a temperature of $25^{\circ} \mathrm{C}$. A solution of bacterial metabolites was separated from living cells by passing through a membrane filter ("Millipore" $0.22 \mu \mathrm{m}$, France). Cell-free culture fluid filtrate was added to the Murashige and Skoog medium (MS0). The standard concentration of culture fluid filtrate of bacteria in the growth medium for plants was calculated so that in 1 liter of MS0 its content corresponded to the amount of culture filtrate per the same number of microbial cells that should be in the bacterial suspension used for processing plants (standard concentration: BsA $-6 \times 10^{7}$ cells $/ \mathrm{ml}$; PfR $-1 \times 10^{6}$ cells $/ \mathrm{ml}$ ). To evaluate the impact of excessive bacterial metabolites on plants, the culture fluid filtrate concentration in MS0 was increased by 2 and 4 times compared to the standard value. Cucumber microplants were planted on the MS0 medium with bacterial metabolites.

The functional state of plants was diagnosed in vitro using the method of induced chlorophyll fluorescence on an "LPT-1FCU" chlorophyll fluorimeter (Russia) in terms of specific photosynthetic activity in arbitrary units $[15,16]$.

Microsoft Office Excel was used for statistical processing and analysis of experimental data.

\section{Results and discussion}

In order to determine the impact of laser irradiation on the activity of bacteria - agents for the biocontrol of plant diseases, we performed a comparative assessment of the number of $\mathrm{CFU}$ in bacterial suspensions treated and untreated with coherent light. The experiment revealed the stimulating effect of laser irradiation in relation to the studied microorganisms (Fig. 1).

It was found that the number of CFU in the suspensions of the PfV and BsP bacteria increased to the greatest extent (by $64.1 \%$ and $66.0 \%$, respectively). At more effective exposure durations ( 240 seconds for PfV and 480 seconds for BsP), stimulation of $120 \%$ and $80 \%$ was observed, respectively. In the irradiated PfV suspension, the number of CFU, depending on the duration of exposure, varied from $7.5 \times 10^{5}$ cells $/ \mathrm{ml}$ to $16.1 \times 10^{5}$ cells $/ \mathrm{ml}$, in the control variant it was $7.3 \times 10^{5}$ cells $/ \mathrm{ml}$. In the experiment with the BsP bacterium, the number of living cells ranged from $2.9 \times 10^{5}$ cells $/ \mathrm{ml}$ to $3.6 \times 10^{5}$ cells $/ \mathrm{ml}$, in the control sample of the suspension this indicator was $2.0 \times 10^{5} \mathrm{cells} / \mathrm{ml}$.

A sufficiently high degree of stimulation was detected upon irradiation of BsA and PfR suspensions (45.9\% and 50.9\%, respectively). On effective exposures, the maximum stimulation was $68.3 \%$ for BsA ( $30 \mathrm{sec})$ and $70.5 \%$ for PfR $(240 \mathrm{sec})$. The number of living structures after irradiation varied depending on the duration of exposure within $9.8 \times 10^{5}$ cells $/ \mathrm{ml}-13.3 \times 10^{5}$ cells $/ \mathrm{ml}$ and $2.0 \times 10^{9}$ cells $/ \mathrm{ml}-2.9 \times 10^{9}$ cells $/ \mathrm{ml}$, respectively, and in the control variants it was $7.9 \times 10^{5}$ cells $/ \mathrm{ml}$ and $1.7 \times 10^{5}$ cells $/ \mathrm{ml}$, respectively.

The BsG bacterium was less sensitive to laser treatment. The degree of stimulation of bacterial cells averaged $4.68 \%$. Depending on the exposure in the experimental variants, the value of the number of CFU ranged from $13.9 \times 10^{5} \mathrm{cells} / \mathrm{ml}$ to $19.5 \times 10^{5} \mathrm{cells} / \mathrm{ml} .15 .9 \times 10^{5}$ cells $/ \mathrm{ml}$ were counted in suspension without treatment with coherent light. The maximum 
degree of stimulation of this bacterium was $22.6 \%$ with the most effective exposure time of 15 seconds.

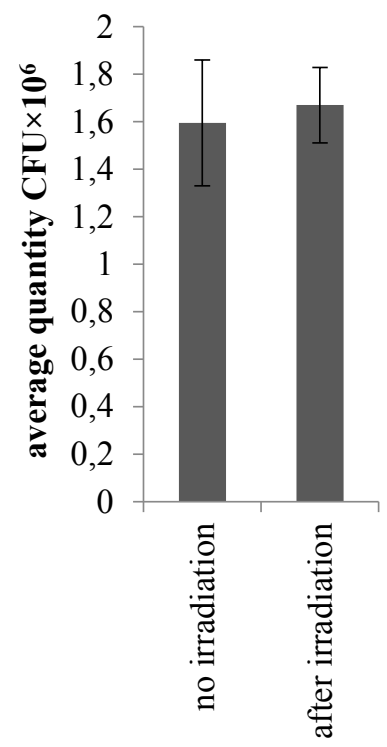

BsG

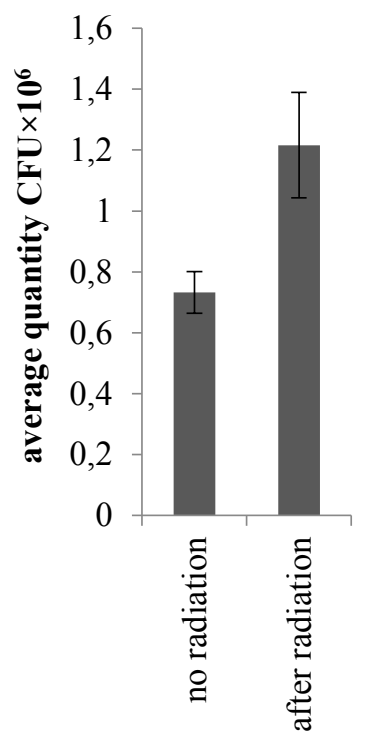

PfV

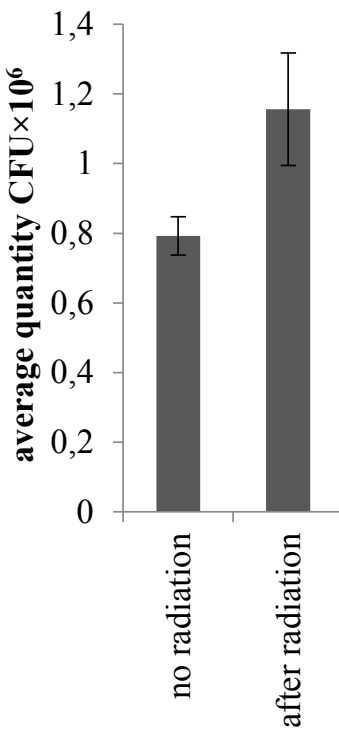

BsA

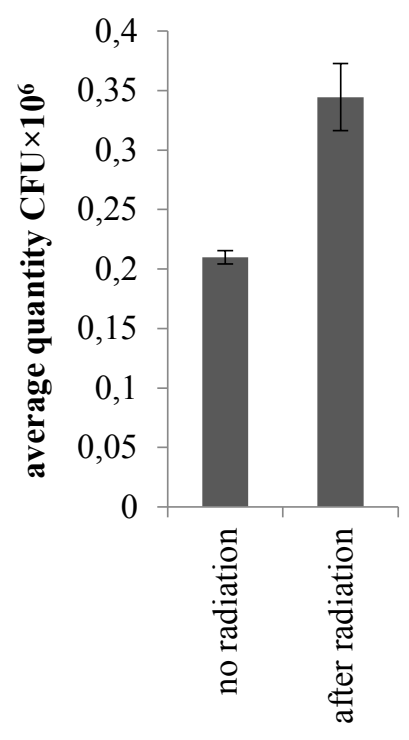

BsP

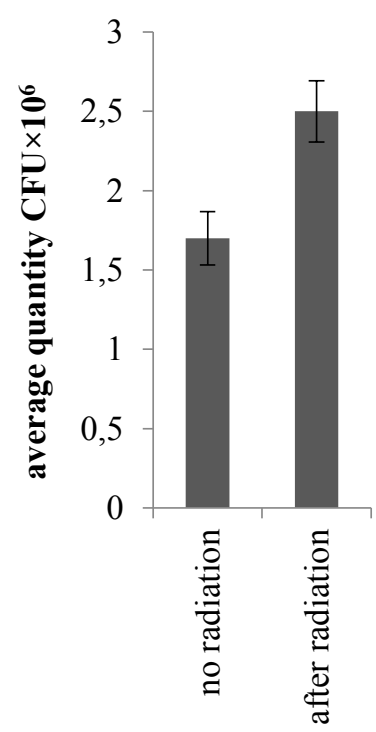

PfR

Fig. 1. Irradiation impact on the number of bacterial CFU in biological products solutions.

Thus, laser irradiation can lead to a doubling of the number of CFU in bacterial suspensions compared to the non-irradiated variants. In this regard, it is necessary to determine impacts of an excessive amount of metabolites synthesized by bacterial cells on plants. This experiment was carried out in the absence of extraneous microbiota, which was achieved using the in vitro culture. An objective assessment of the functional state of plants 
was given by the diagnosis of photosynthesis activity by the method of induced chlorophyll fluorescence (Fig. 2, 3).

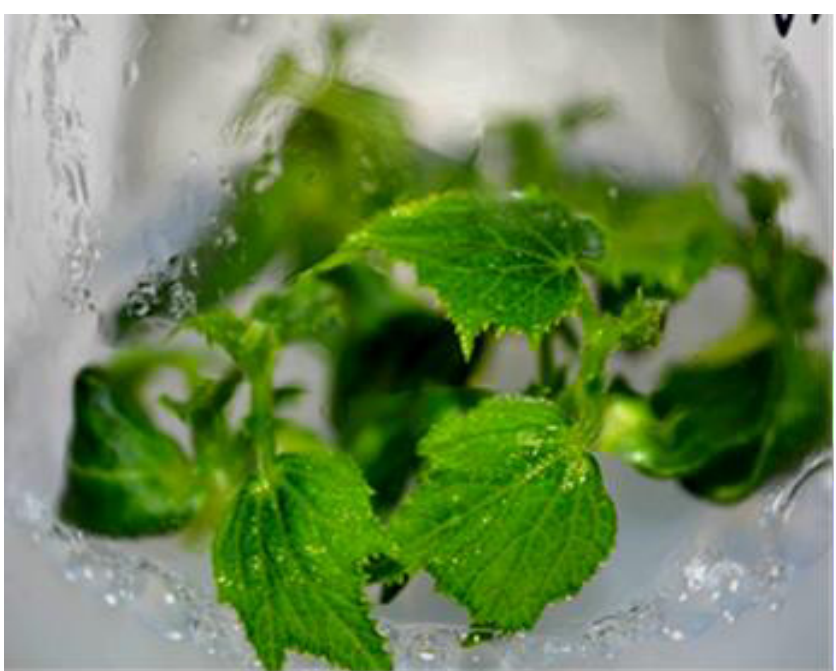

Fig. 2. Cucumber microplants in vitro culture.

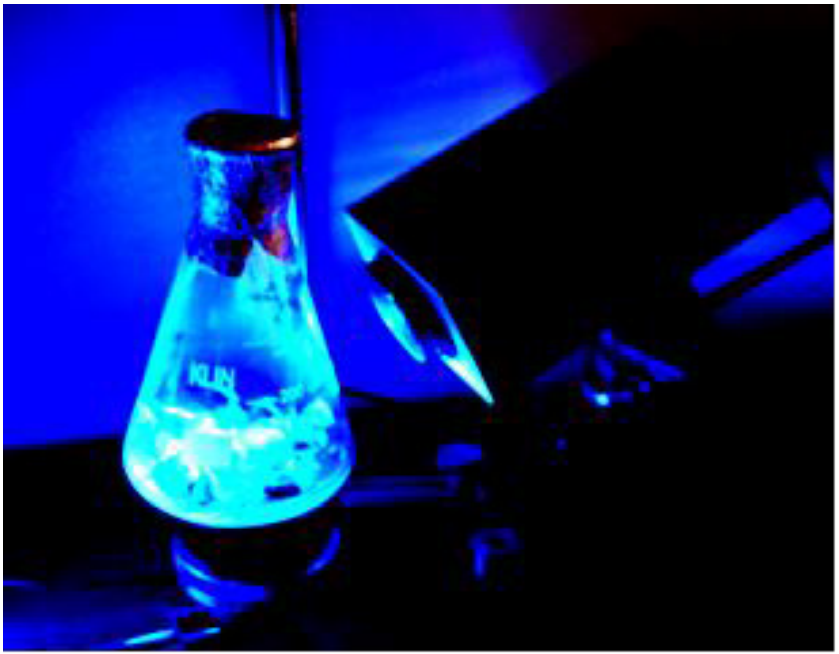

Fig. 3. Process of measuring the photosynthetic activity of cucumber microplants in vitro.

Impact of microbial metabolites cucumber microplants was studied using culture filtrates, $\mathrm{BsG}, \mathrm{BsP}, \mathrm{PfV}$. At culture fluid filtrate concentrations of 2 and 4 times higher than the standard, a change in photosynthetic activity with a tendency to increase was noted in chlorophyll-containing tissues of the studied objects. An excess of the studied indicator was revealed with a twofold increase compared to the standard content in the medium by $32.5 \%$ and with a fourfold increase by $32.2 \%$ (Fig. 4).

The greatest increase in photosynthetic activity in cucumber seedlings was observed in variants with an increased concentration of the BsG, PfV and BsP bacteria metabolites by an average of $111.4 \%, 71.8 \%$ and $37.5 \%$, respectively. In the BsA and PfR, the change in this indicator was insignificant and fluctuated within the standard error.

Studies have shown that an increase in the number of metabolites in the MS0 medium does not adversely affect the functional state of chlorophyll-containing tissues. 


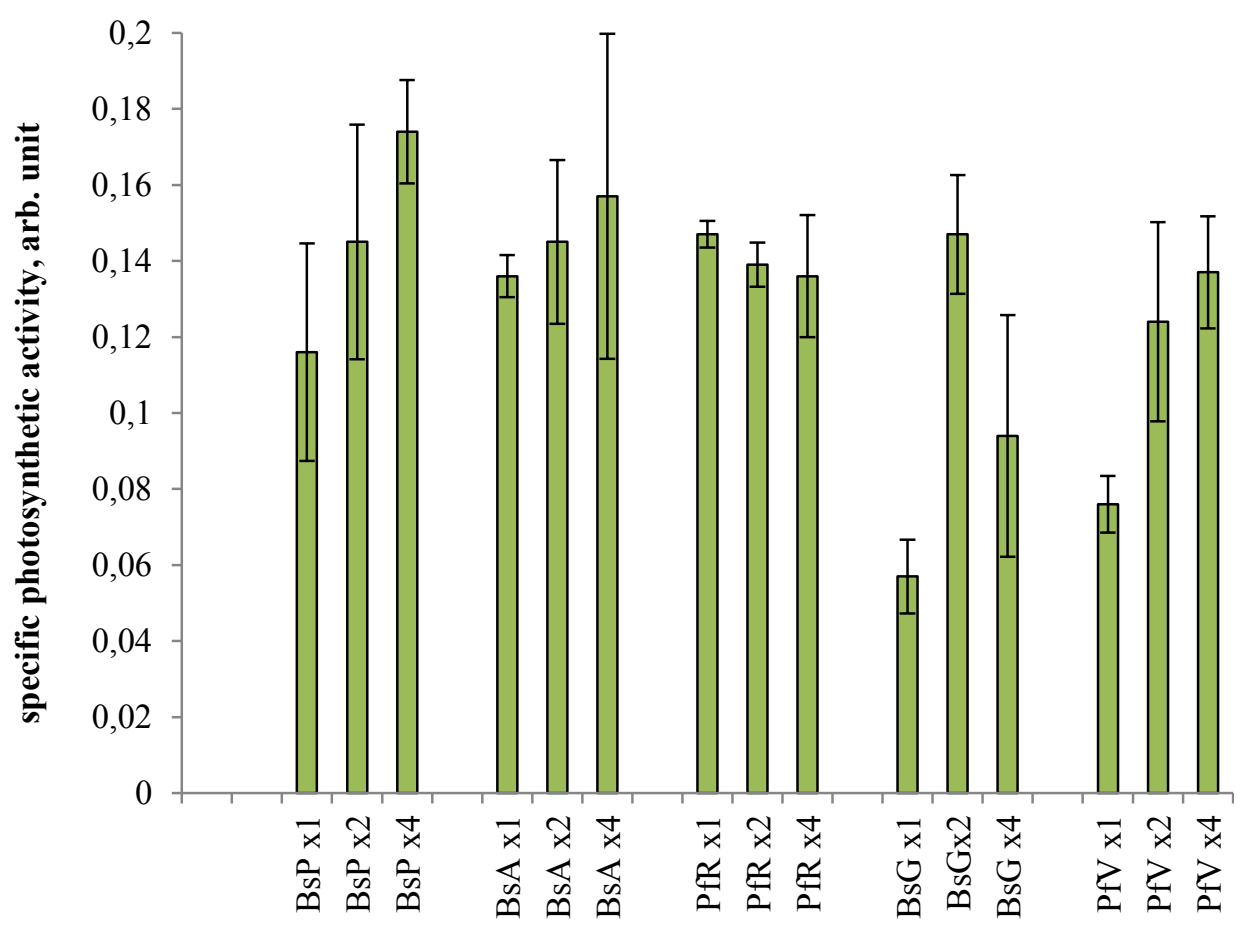

Fig. 4. Impact of the bacterial metabolites of protective biological products on the rate of specific photosynthetic activity $\left(\mathrm{Kf}_{\mathrm{T}}\right)$ in cucumber microplants in an in vitro culture.

\section{Conclusion}

On the example of cucumber microplants using a chlorophyll fluorimeter to assess the plants' functional activity under in vitro conditions, it was found that excessive accumulation of bacterial metabolites in the substrate, which can occur as a result of laser stimulation of phytopathogenic bacteria-antagonists, does not adversely affect plant tissues. This proves the safety of using bacterial suspensions after laser stimulation for plant treatment.

This work was carried out as part of the state assignment of the Ministry of Agriculture of the Russian Federation at the expense of the state budget.

\section{References}

1. S. Horuz, Y. Aysan, Plant Protect. Sci. 54, 138-146 (2018). DOI: 10.17221/168/2016PPS

2. S. Suzuki, Y. Hel, H. Oyaizul, Curr Microbiol 47, 138-143 (2003). DOI: 10.1007/s00284-002-3968-2

3. P. R. Hardoim, L. S. van Overbeek, G. Berg, A. M. Pirttilä, S. Compant, A. Campisano, M. Döring, A. Sessitsch, MMBR 79, 293-320 (2015). DOI: 10.1128/MMBR.00050-14

4. V. K. Chebotar, N. V. Malfanova, A. V. Shcherbakov, G. A. Ahtemova, A. Y. Borisov, B. Lugtenberg, I. A. Tikhonovich, Appl Biochem Microbiol 51, 732 (2015). DOI: 10.1134/S0003683815060174 
5. M. Kilian, U. Steiner, B. Krebs, H. Junge, G. Schmiedeknecht, R. Hain, PflanzenschutzNachrichten Bayer 1, 72-93 (2000).

6. Yu. Yu. Pavlovets, I. Yu. Saharuta, O. V. Lagodich, A. V. Lagodich, Biologically active preparations for plant growing. Scientific background-Recommendations - Practical results, 152-153 (Belarusian State University, Minsk, 2018)

7. G. A. Iutinskaya, Biologically active preparations for plant growing. Scientific background - recommendations - practical results, 93-96 (Kiev, 2019)

8. M. V. Maslova, E. V. Grosheva, A. V. Budagovsky, O. N. Budagovskaya, Amazonia investiga 8, 610-616 (2019)

9. S. A. Muratova, M. B. Yankovskaya, N. V. Solovykh, D. G. Shornikov, A. V. Budagovsky, R. V. Papikhin, Pomiculture and small fruits culture in Russia 26, 375-382 (2011)

10. J. S. Sun, Mixtures of surfactants for auxin-based herbicides: RU patent No. 2571051. Application: $\quad 02 / 22 / 2011$; $\quad$ publication: 12.20 .2015 . https://rusneb.ru/catalog/000224_000128_0002571051_20151220_C2_RU/

11. Zh. Z. Guralchuk, E. Yu. Morderer, Fiziol. rast. genet. 49, 3-14 (2017). DOI: 10.15407/frg2017.01.003

12. Ye. Yu. Morderer, Zh. Z. Guralchuk, V. V. Morgun, Ukr. Bot. J. 75, 552-563 (2018). DOI: $10.15407 / \mathrm{ukrbotj} 75.06 .552$

13. M. E. Zain, A. A. Razak, H. H. El-Sheikh, H. G. Soliman and A. M. Khalil, African Journal of Microbiology Research 3, 280-286 (2009)

14. T. Murashige, F. Skoog, Physiologia Plantarum 15, 473-497 (1962). DOI: 10.1111/j.1399-3054.1962.tb08052.x

15. A. V. Budagovsky, O. N. Budagovskaya, I. A. Budagovsky, Photonics Russia 6, 22-28 (2010)

16. O. N. Budagovskaya, A. V. Budagovsky, Method of non-destructive diagnosis of the functional state of plants ex vitro and in vitro: patent RU No. 2688464. Application: 03/20/2018; publication:

05.21.2019. https://rusneb.ru/catalog/000224_000128_0002688464_20190521_C1_RU/ 